\title{
Physicochemical Properties of Duck Feet Collagen with Different Soaking Time and Its Application in Surimi
}

\author{
Chong Hui Theng ${ }^{\#}$, Nurul Huda ${ }^{*}$, Nik Aisyah Nik Muhammad*, Chatarina Wariyah ${ }^{+}$, \\ Haslaniza Hashim \\ ${ }^{\#}$ Food Technology Program, Universiti Sains Malaysia, Minden, 11800, Penang, Malaysia \\ *Institute for Community (Health) Development, Universiti Sultan Zainal Abidin, \\ Gong Badak Campus, 21300, Terengganu Darul Iman, Malaysia \\ ${ }^{\$}$ School of Food Industry, Faculty of Bioresources and Food Industry, Universiti Sultan Zainal Abidin, \\ Besut Campus, 22200, Terengganu Darul Iman, Malaysia \\ Email: nhuda@unisza.edu.my \\ ${ }^{+}$Department of Food Science, Faculty of Agroindustry, Mercu Buana University of Yogyakarta, \\ 55753, Yogyakarta, Indonesia \\ ^School of Chemical Sciences and Food Technology, Faculty of Science and Technology, Universiti Kebangsaan Malaysia 43600, UKM, \\ Bangi, Selangor, Malaysia
}

\begin{abstract}
Duck feet are considered as waste products because people normally do not consume duck feet. It is highly available in Malaysia and thus has the high potential to be the alternative source to produce collagen other than fish, bovine or porcine. The main objective of this study is to evaluate the physicochemical properties of different treated duck feet collagen and its effect on the quality of sardine surimi. Duck feet was stirred and soaked in $5 \%$ lactic acid solution for different time $(12,24,36$ and $48 \mathrm{~h})$ at $4^{\circ} \mathrm{C}$. Another treatment for the duck feet is demineralization. Duck feet collagen was demineralized by 0.5M EDTA solution for $24 \mathrm{~h}$ prior soaking in lactic acid solution for $24 \mathrm{~h}$. Soaking time 24, 36 and $48 \mathrm{~h}$ has successfully decreased fat content of duck feet collagen significantly compared to $12 \mathrm{~h}$. However, no differences in yield were observed for the samples. Prolong soaking time produced duck feet collagen with higher content of imino acid (hydroxyproline + proline). The intensity of lightness $\left(L^{*}\right)$ for the demineralized duck feet collagen is lower compared to duck feet collagen which was not treated by EDTA. Duck feet collagen has the ability to improve the quality of sardine surimi gel by enhancing its lightness, water holding capacity, gel strength and texture with low cooking loss and expressible moisture. The folding test score of sardine surimi gel has been increased from 3.00 to 5.00 by the addition of duck feet collagen. The gel strength for sardine surimi gel with the addition of duck feet collagen is in the range of 2625.90 g.mm to $2681.58 \mathrm{~g} . \mathrm{mm}$, which is approximately 9 times higher than the gel strength of sardine surimi without collagen $(280.43 \mathrm{~g} . \mathrm{mm})$.
\end{abstract}

Keywords - duck feet; collagen; EDTA; sardine surimi

\section{INTRODUCTION}

Duck meat can be sorted as poultry meat, and its production is increasing gradually yearly. There is around 10million of ducks are slaughtered every year in Malaysia. Malaysian Government fosters the duck meat production by enforcing National Agriculture policy so that the requirements by the population can be enhanced with time [1]. People mainly do not consume duck feet, normally they are considered as waste material. Duck feet have the potential to be the alternative source of collagen other than porcine and bovine. There are studies which are related to poultry feet collagen. Reference [2] extracted the collagen containing melanin from silky fowl feet by different acids; Reference [3] pointed out the optimum condition for extraction of collagen from chicken feet. Meanwhile, reference [4] and [5] performed a preliminary study on the physicochemical properties of duck feet collagen and the effect of duck feet collagen addition on the physicochemical properties of surimi.

Collagens are the most abundant proteins in the animal body. There are about $25 \%$ of collagen in the animal body [6]. Collagens have been traditionally extracted from the skins or bones of mammals, mainly of bovine and porcine and also from marine sources such as fish collagens (skin, scales, and bones). Poultry feet collagens have been 
extracted as medical such as collagen film, and collagen powder for wound exudates control due to the high collagen contents in the poultry feet [7], [8]. In recent years, consumers refuse to use products that are produced from bovine collagen or gelatin due to its potential risks of infectious diseases [9], [10], [11] such as bovine spongiform encephalopathy (BSE). On the other hand, pig collagen is not suitable to be used in certain products due to religious reasons [12].

The special physic-chemical and functional properties of collagen make it highly demanded the food processing in the food industry [13]. A study performed by reference [14] showed that collagen has high gelling properties, swelling properties, and foaming properties even without gelling. Pork collagen has been used in restructured beef to improve its cooking yields and tensile strength [5]. A strong acid is efficient to increase collagen extraction rate, but too low $\mathrm{pH}$ value can cause denaturation and digestion of collagen in extraction [16]. For this reason, lactic acid is desirable for extraction of collagen because it is a weak acid.

Surimi is a Japanese term for minced fish which can be defined as the wet concentrated of fish muscle that is mechanically deboned, minced, washed, mixed with cryoprotectant before freezing to prolonger frozen shelf life storage [17]. Fish muscle can be categorized into white and dark muscle. Dark-fleshed fish like tunas have more dark muscle with haem proteins and lipids compared to whitefleshed fish like cod species and flatfish. Thus, the flavor and colour of surimi made from dark-fleshed fish will be influenced [18]. Studies done by reference [19] have shown that dark flesh contains higher essential amino acids content than the white flesh of oil sardine (Sardinella longiceps). Worldwide, there are high catches of dark muscle fish species used for food production, especially for surimi production. Thus, dark muscle fish has the potential to be the alternative raw material for surimi production since there are limited fish resources for surimi production. Sardine has a high content of dark muscle which makes up a high level of lipid and myoglobin [20]. Myoglobin and hemoglobin are associated with the whiteness of surimi [21]. According to reference [22], sardine surimi has a darker colour and poorer gel properties than lean fish surimi. All these factors cause the low quality of sardine surimi. Collagen could be the additives in surimi due to its physicochemical properties which are expected to enhance the quality of surimi products.

The main objectives of this project are to study the effect of different soaking time $(12,24,36,48 \mathrm{~h})$ during collagen extraction on the physicochemical properties of duck feet collagen, to evaluate the effect of EDTA during collagen extraction on the physicochemical properties of duck feet collagen and to determine the effect of duck feet collagen on the physicochemical properties of sardine surimi.

\section{MATERIALS AND METHODS}

\section{A. Samples}

Duck feet were supplied from Perak Duck Food Industries Sdn. Bhd which is located in Taiping, Perak, Malaysia. The frozen duck feet were stored at $-20^{\circ} \mathrm{C}$ for further extraction and analysis. Lactic acid $88 \%$ and sodium hydroxide were used to extract the duck feet collagen.

\section{B. Collagen Extraction}

Collagen was extracted by using acid extraction method as described by reference [3]. Duck feet were thawed for 24 $\mathrm{h}$ at $6^{\circ} \mathrm{C}$. Then, the duck feet's nails were removed, and the duck feet were cut into small pieces. Next, duck feet pieces were ground by using a $10 \mathrm{~mm}$ plate with mechanical mincer (Model EVE/ALL-12, Rheninghaus, Torino, Italy). Then, the grounded duck feet were decalcified using EDTA solutions by soaking it in 0.5M EDTA solutions ( $\mathrm{pH} 7.5$ ) for 24 hours at $4 \mathrm{oC}$ [23]. After that, the ground duck feet were soaked and stirred in 5\% lactic acid solution by w/v (duck feet/solution $=1 / 8)$ with different soaking time $(12,24,36$ and $48 \mathrm{~h}$ ) at $4-7^{\circ} \mathrm{C}$. The purpose of this step is to isolate the collagen duck feet paste and determine the optimum soaking time for collagen extraction. The layer of fat on the surface of the solution was disposed of. The treated duck feet suspended solutions were homogenized in a blender (Panasonic, MX-799) for 5 min (15 sec work and $5 \mathrm{sec}$ rest) and then filtered by gauze to discard the residues. The suspended solutions were neutralized to $\mathrm{pH} 7$ with $1.0 \mathrm{~N}$ $\mathrm{NaOH}$. The neutral solutions were centrifuged with a highspeed centrifuge (Model Union 5KR, Korea) for $15 \mathrm{~min}$ at $5000 \mathrm{~g}$ and $10^{\circ} \mathrm{C}$. The supernatant was discarded, and the sediment was lyophilized by a freeze dryer (LD53, Kingston, New York) to get dried collagen.

\section{Surimi Gel Preparation}

The gels were prepared by referring to the method of reference [24]. The frozen surimi samples were thawed at $4^{\circ} \mathrm{C}$ overnight. The surimi was blended for 2 min with $3 \%$ salt and $2 \%$ collagen using a high-speed cutter mixer (Robert Coupe ${ }^{\circledR}$, Model Blixer®, 3B, FRANCE). The mixed surimi was stuffed into $2.5 \mathrm{~cm}$ diameter casings and heated in a water bath (Model WB-22, Korea) for 30 minutes at $36^{\circ} \mathrm{C}$ and then cooked for 10 minutes at $90^{\circ} \mathrm{C}$. After cooking, all gels were immediately cooled in iced water for 30 minutes and stored overnight at $4^{\circ} \mathrm{C}$ prior to analysis.

\section{Yield, $p H$, and Swelling Percentage}

The yield and swelling percentage of collagen were determined according to the method of reference [3] by using the formula below:

$$
\text { Yield }(\%)=\frac{\text { Wetght of frozen dried crude collagen }}{\text { Weight of ground duck feet }} X 100
$$

$$
\text { Swelling (\%) }=\frac{\text { Weight of the super }- \text { solid filtered product after soaking }}{\text { Weight of ground duck feet before soaking }} X 100
$$

while $\mathrm{pH}$ values of collagen were measured according to reference [25] by using $\mathrm{pH}$ meter (Mettler Toledo Delta 320).

\section{E. Chemical Composition}

The chemical composition (moisture, ash, fat, and protein) content of extracted and dried collagen was determined according to the reference [26] 


\section{F. Amino Acids Analysis}

According to the method of reference [27], the collagen was analyzed in duplicate with three hydrolyses $(6 \mathrm{~N} \mathrm{HCl}$, performic acid $+6 \mathrm{~N} \mathrm{HCl}$ and $4.2 \mathrm{~N} \mathrm{NaOH}$ ). Samples were hydrolyzed with $6 \mathrm{~N} \mathrm{HCl}$ to obtain hydrolysates suitable for analysis of all amino acids except cystine+cysteine and tryptophan and methionine. The samples were hydrolyzed at $110^{\circ} \mathrm{C}$ with widely different sample weights and volumes of acids for 22 hours. Samples oxidized with performic acid were also hydrolyzed with $6 \mathrm{~N} \mathrm{HCl}$ to obtain hydrolysates suitable for the determination of cystine+cysteine as cysteic acid. Then, samples were hydrolyzed with $4.2 \mathrm{~N} \mathrm{NaOH}$ for the determination of tryptophan. The hydrolysates were then applied to an amino analyser (MLC-703); Atto Co., Tokyo, Japan).

\section{G. Determination of Colour}

Colour determination of duck feet collagen was done by referring to the method of [4]. Colourimeter Minolta model CM-3500d spectrophotometer (Minolta, Kyoto, Japan) was used for the colour determination. $\mathrm{L}$ indicates lightness (perfect black $=0$; pure white $=100),(+) \mathrm{a},(-) \mathrm{a},(+) \mathrm{b}$ and $(-)$ $\mathrm{b}$ values indicate redness, greenness, yellowness and blueness respectively.

\section{H. Fourier Transform Infrared Spectroscopy (FTIR) Analysis}

Based on the method of reference [28], FTIR spectra were obtained from $1 \mathrm{mg}$ collagen in approximately $100 \mathrm{mg}$ of potassium bromide $(\mathrm{KBr})$. All spectra were obtained from 4000 to $500 \mathrm{~cm}-1$ at a data acquisition rate of $2 \mathrm{~cm}-1$ by using the FT-IR spectrophotometer (Nicolet iS10, USA).

\section{Folding Test}

Folding test was performed according to the method of reference [29]. Cooked samples were cut into slices with $3 \mathrm{~mm}$ thickness. Then, samples were held between the thumb and forefinger in order to observe the conditions of folded samples. The samples were evaluated by the five points system as follow: (grade AA = No cracks after folding into quarters; grade $\mathrm{A}=$ No cracks after folding in half; grade $\mathrm{B}$ = cracks gradually when folded into half; grade $\mathrm{C}=$ cracks immediately when folded in half; grade $\mathrm{D}=$ breaks by finger pressure).

\section{J. Cooking Loss}

Cooking loss was determined according to reference [30]. Each chilled gel was removed from the plastic tube, blotted dry with a paper towel and weighed after following overnight storage. Overall cook loss of samples was calculated as a percentage of raw stuffed weight based on the equation below:

$$
\text { Cooking loss }(\%)=\frac{\text { Cooked gel weight }}{\text { uncooked gel weight }} X 100
$$

\section{K. Water Holding Capacity (WHC)}

Water holding capacity of the samples was analysed based on the method of reference [30]. Gels (25 x 15mm) of known weight were put into the tubes and centrifuged (Sorvall RC 5B Plus, Du Pont) at low speed (365g) for 20 mins at $4^{\circ} \mathrm{C}$.WHC of the samples were calculated as the equation below:

WHC $(\%)=\frac{\text { Weight of gel before centrifuge }- \text { weight of gel after centrifuge }}{\text { Weight of gel before centrifuge }} \times 100$

\section{Expressible Moisture (EM)}

EM was determined according to the method of reference [31]. Samples were cut into a thickness of $5 \mathrm{~mm}$ and weighed. The samples were placed between two pieces of Whatman paper No.41 at the bottom and top of the sample. A standard weight $(5 \mathrm{~kg})$ was placed on top of the sample for 2 mins. Then, the samples were weighed again. EM was calculated by using the formula below:

$$
E M(\%)=\frac{\text { Weight of prepressed sample }(\mathrm{g})-\text { weight of pressed sample }}{\text { Weight of prepressed sample }(\mathrm{g})} X 100
$$

\section{Gel Strength}

According to reference [32], textural analysis of gels was performed by the computer-assisted TA.XT Plus (Stable Micro System, Godalming, UK). The samples were cut into cylindrical shapes with the length of $2.5 \mathrm{~cm}$. The cooked gels were equilibrated and tested at room temperature. The breaking force $(\mathrm{g})$ and deformation $(\mathrm{mm})$ were analyzed by using the texture analyzer equipped with a spherical plunger. The probe $(\mathrm{P} / 0.25 \mathrm{~S})$ was pressed into the cut surface of a gel specimen perpendicularly at a constant speed of $1 \mathrm{~mm} / \mathrm{sec}$ for a distance of $15 \mathrm{~mm}$. The trigger force used was $5 \mathrm{~g}$, with $1 \mathrm{~mm} / \mathrm{sec}$ of pre-test speed and $1 \mathrm{~mm} / \mathrm{sec}$ of post-test speed. The load cell capacity of the texture analyzer was $30 \mathrm{~kg}$, and the return distance was $35 \mathrm{~mm}$. Gel strength of the samples was calculated by multiply the value of breaking force $(\mathrm{g})$ with deformation $(\mathrm{mm})$.

\section{N. Texture Profile Analysis (TPA)}

According to the method of reference [33], texture profile analysis of the gels was performed by using Texture Analyzer Model TA-XT2 (Stable Micro System, Godalming, UK). Before analysis, the gels were equilibrated at room temperature $\left(25-27^{\circ} \mathrm{C}\right)$. The samples were then cut into $3 \mathrm{~cm}$ in length and tested by texture analyser. Compression Platen (SMS P/75) with a heavy-duty platform and the following settings: load cell, 25kg; speed, $3.0 \mathrm{~mm}$ sec-1; test speed, $1.0 \mathrm{~mm}$ sec-1; post-test speed, $3.0 \mathrm{~mm}$ sec-1; prefixed strain, $75 \%$; a time before compression, $2 \mathrm{sec}$. The following texture parameters were determined from the TPA curves: hardness at $25 \%$ of deformation, springiness, cohesiveness, gumminess, and chewiness. Hardness was defined by peak force during the first compression cycle. Cohesiveness was calculated as the ratio of the area under the second curve to the area under the first curve. Springiness was defined as the ratio of time recorded between the start of the second area and the second probe reversal to the time recorded between the start of the first area and the first probe reversal. Chewiness was obtained by multiplying hardness and cohesiveness. 


\section{O. Colour Analysis of Surimi Gel}

Colour analysis of the surimi gel samples was determined according to reference [4] using colourimeter Minolta model CM-3500d spectrophotometer (Minolta Kyoto, Japan).

\section{P. Statistical Analysis}

The statistical package used was SPSS 16 (SPSS Inc, Chicago IL) and significance was established at 0.05 levels. All chemical analyses were performed in triplicate.

\section{RESULT AND DISCUSSIONS}

\section{A. Yield, $p H$, and Swelling Percentage}

The yield, $\mathrm{pH}$ and swelling percentage of duck feet collagen treated with different soaking time and EDTA are presented in Table 1 . No significant difference $(p>0.05)$ was observed for the yield between the feet collagen extracted by various soaking time. The yield for duck feet collagen extracted by various soaking time was around $28.40 \%$ (12 h$28.43 \%, 24 \mathrm{~h}-28.32 \%, 36 \mathrm{~h}-28.43 \%, 48 \mathrm{~h}-28.49 \%$ ) whereas the yield for EDTA treated duck feet collagen was lower, which was $26.66 \%$. The lower yield of EDTA treated duck feet collagen could be caused by the loss of ash content during demineralization process. According to the results presented by reference [3], the highest yield obtained for lactic acid treated broiler chicken feet collagen was $30.88 \%$.

TABLE I

The Yield, PH AND Swelling PeRCENTAGe of Demineralised DucK FEET COLLAGEN

\begin{tabular}{|l|l|l|l|}
\hline Sample & \multicolumn{4}{|c|}{ Yield (\%) } & \multicolumn{1}{|c|}{ pH } & \multicolumn{1}{c|}{$\begin{array}{c}\text { Swelling } \\
\text { percentage }(\%)\end{array}$} \\
\hline $12 \mathrm{~h}$ & $28.43 \pm 0.29^{\mathrm{a}}$ & $2.74 \pm 0.02^{\mathrm{b}}$ & $233.10 \pm 0.96^{\mathrm{c}}$ \\
\hline $24 \mathrm{~h}$ & $28.32 \pm 0.18^{\mathrm{a}}$ & $2.68 \pm 0.01^{\mathrm{e}}$ & $235.43 \pm 0.55^{\mathrm{b}}$ \\
\hline $36 \mathrm{~h}$ & $28.43 \pm 0.28^{\mathrm{a}}$ & $2.70 \pm 0.01^{\mathrm{d}}$ & $240.71 \pm 0.38^{\mathrm{a}}$ \\
\hline $48 \mathrm{~h}$ & $28.49 \pm 0.17^{\mathrm{a}}$ & $2.71 \pm 0.01^{\mathrm{c}}$ & $241.31 \pm 0.64^{\mathrm{a}}$ \\
\hline EDTA & $26.66 \pm 0.27^{\mathrm{b}}$ & $2.83 \pm 0.01^{\mathrm{a}}$ & $232.52 \pm 0.44^{\mathrm{c}}$ \\
\hline
\end{tabular}

Values are mean \pm standard deviation.

abcde :Means within the same column with different letters are significantly different $(\mathrm{p}<0.05)$

The $\mathrm{pH}$ values for the duck feet collagen were in the range of 2.68 to 2.83 , which were similar to the silky fowl feet (2.75) but slightly higher than chicken feet collagen (2.54 to 2.72) [2], [3]. Strong acid helps to enhance collagen extraction efficiency. Nevertheless, $\mathrm{pH}$ values lower than 2.0 could cause denaturation and digestion of collagen in the extraction [16]. The swelling percentage increased as the soaking time increased (12 h-233.10\%, 24 h-235.43\%, 36 h$240.71 \%, 48 \mathrm{~h}-241.31 \%)$. The swelling percentage of the samples was slightly lower than silky fowl feet $(251.2 \%)$ and chicken feet (246.4\%) [2], [3].

\section{B. Chemical Composition}

Table 2 shows the chemical composition of duck feet collagen with various treatments, commercial bovine, and fish collagen. There were no significant differences $(p>0.05)$ in moisture, protein, and fat for the duck feet collagen soaked for $24 \mathrm{~h}, 36 \mathrm{~h}$, and $48 \mathrm{~h}$. The moisture content $(15.87 \%)$ of duck feet collagen which was demineralized by EDTA was significantly higher $(\mathrm{p}<0.05)$ than duck feet collagen treated with various soaking time (12 h-6.63\%, 24 h-7.36\%, $36 \mathrm{~h}-7.48 \%, 48 \mathrm{~h}-7.43 \%)$ and commercial collagen (bovine-8.79\%, fish-4.57\%). For raw duck feet, the high moisture content $(58.13 \%)$ could be caused by the lack of drying process.

Raw duck feet contained $22.45 \%$ of protein, which was higher than the protein content of broiler chicken feet $(17.42 \%)$ [3]. Duck feet collagen soaked for $12 \mathrm{~h}$ shows significantly lower protein content $(32.91 \%)$ than duck feet collagen soaked in $24 \mathrm{~h}, 36 \mathrm{~h}$ and $48 \mathrm{~h}(38.57 \%, 38.48 \%$, and $38.55 \%$ respectively). The protein content of commercial bovine $(98.96 \%)$ and fish collagen $(92.10 \%)$ was significantly higher $(\mathrm{p}<0.05)$ than the duck feet collagen.

TABLE II

Chemical Composition of Demineralized Duck Feet Collagen

\begin{tabular}{|l|c|c|c|c|}
\hline Sample & $\begin{array}{c}\text { Moisture } \\
(\%)\end{array}$ & Protein $(\%)$ & Fat $(\%)$ & Ash (\%) \\
\hline $12 \mathrm{~h}$ & $6.63 \pm 0.27^{\mathrm{d}}$ & $32.91 \pm 0.46^{\mathrm{e}}$ & $34.16 \pm 0.24^{\mathrm{a}}$ & $25.36 \pm 0.28^{\mathrm{a}}$ \\
\hline $24 \mathrm{~h}$ & $7.36 \pm 0.26^{\mathrm{c}}$ & $38.57 \pm 0.30^{\mathrm{c}}$ & $28.41 \pm 0.44^{\mathrm{c}}$ & $24.46 \pm 0.36^{\mathrm{bc}}$ \\
\hline $36 \mathrm{~h}$ & $7.48 \pm 0.29^{\mathrm{c}}$ & $38.48 \pm 0.23^{\mathrm{c}}$ & $28.17 \pm 0.77^{\mathrm{c}}$ & $24.73 \pm 0.37^{\mathrm{b}}$ \\
\hline $48 \mathrm{~h}$ & $7.43 \pm 0.17^{\mathrm{c}}$ & $38.55 \pm 0.25^{\mathrm{c}}$ & $27.95 \pm 0.49^{\mathrm{c}}$ & $24.36 \pm 0.24^{\mathrm{c}}$ \\
\hline EDTA & $15.87 \pm 0.22^{\mathrm{a}}$ & $37.56 \pm 0.19^{\mathrm{d}}$ & $29.94 \pm 0.39^{\mathrm{b}}$ & $14.95 \pm 0.47^{\mathrm{d}}$ \\
\hline Bovine & $8.79 \pm 0.09^{\mathrm{b}}$ & $90.26 \pm 0.15^{\mathrm{a}}$ & $1.03 \pm 0.11^{\mathrm{d}}$ & $0.36 \pm 0.02^{\mathrm{f}}$ \\
\hline Fish & $4.57 \pm 0.18^{\mathrm{e}}$ & $87.89 \pm 0.53^{\mathrm{b}}$ & $0.86 \pm 0.08^{\mathrm{e}}$ & $7.32 \pm 0.16^{\mathrm{e}}$ \\
\hline $\begin{array}{l}\text { Raw Duck } \\
\text { Feet }\end{array}$ & $58.13 \pm 0.12$ & $22.45 \pm 0.26$ & $11.98 \pm 0.47$ & $7.31 \pm 0.13$ \\
\hline
\end{tabular}

Values are mean \pm standard deviation.

abcdef :Means within the same column with different letters are significantly different $(\mathrm{p}<0.05)$.

The fat content $(11.98 \%)$ of raw duck feet was about the same with broiler chicken feet $(12.04 \%)$ [3]. The fat content of duck feet collagen decreased with soaking time (12 h$34.16 \%$, 24 h-28.41\%, 36 h-28.17\%, 48 h-27.95\%). Demineralized duck feet collagen contained $29.94 \%$ of fat content. The fat content of commercial bovine $(1.03 \%)$ and fish collagen $(0.86 \%)$ was significantly lower than duck feet collagen. The high-fat content of duck feet collagen is due to the absence of defatting process. Raw duck feet contained higher ash content $(7.31 \%)$ than raw broiler chicken feet (5.98\%) [3]. The total ash content of duck feet collagen treated with various soaking time (12 h-25.36\%, $24 \mathrm{~h}$ $24.46 \%$, $36 \mathrm{~h}-24.73 \%$, $48 \mathrm{~h}-24.36 \%$ ) was significantly higher than commercial bovine and fish collagen $(0.36 \%$ and $7.32 \%$ respectively). The ash content in duck feet has been reduced to $14.95 \%$ by using $0.5 \mathrm{M}$ EDTA in $24 \mathrm{~h}$; it was significantly lower than the duck feet collagen soaked for a different time. The high ash content of the duck feet collagen could be associated with the high amount of bone residue [3].

\section{Amino Acid Composition}

The amino composition of different treated duck feet collagen and chicken feet collagen are shown in Table 3. 19 amino acids were detected in the duck feet collagen which has been treated with EDTA and soaked for different time (12 h, $24 \mathrm{~h}, 36 \mathrm{~h}$ and $48 \mathrm{~h}$ ). Glycine and imino acid are essential for gel strength, especially hydroxyproline and proline which are associated with the gelling attribute. Low level of amino acids represents a poor gelling ability [34]. 
Glycine (Gly) was the main amino acid detected in all the duck feet collagen samples. Duck feet collagen which had been demineralized in $0.5 \mathrm{M}$ of EDTA for $24 \mathrm{~h}$ contained higher amount of Gly $(61.88 \mathrm{mg} / \mathrm{g})$ compared to duck feet collagen which do not undergo demineralization (12 h-44.60 mg/g, 24 h-53.59 mg/g, 36 h-51.31 mg/g, 48 h-61.88 mg/g). However, the amount of Gly in duck feet collagen was far lower to chicken feet collagen $(282.50 \mathrm{mg} / \mathrm{g})$ [3].

The amino acids proline (Pro) and hydroxyproline (HyP) contribute to the rigidity of the collagen structure [35]. From the result, a higher amount of proline $(36.39 \mathrm{mg} / \mathrm{g}$ ) and hydroxyproline $(32.11 \mathrm{mg} / \mathrm{g})$ was found in EDTA treated duck feet collagen compared to duck feet collagen soaked for different time (Pro: 12 h-26.54 mg/g, 24 h-33.50, 36 h$33.30 \mathrm{mg} / \mathrm{g}, 48 \mathrm{~h}-31.05 \mathrm{mg} / \mathrm{g}$ and HyP: $12 \mathrm{~h}-22.73 \mathrm{mg} / \mathrm{g}, 24$ h-29.23, 36 h-28.38 mg/g, 48 h-27.09 mg/g). No hydroxyproline was detected, and $107.50 \mathrm{mg} / \mathrm{g}$ of proline was found in chicken feet collagen [3].

TABLE III

The Amino Acid Composition of Demineralized Duck FeEt Collagen SAMPles (MG/G)

\begin{tabular}{|l|c|c|c|c|c|c|}
\hline Amino Acid (mg/g) & $\mathbf{1 2 h}$ & $\mathbf{2 4 h}$ & $\mathbf{3 6 h}$ & $\mathbf{4 8 h}$ & EDTA & *Chicken feet Collagen \\
\hline Histidine & 3.40 & 4.88 & 4.87 & 4.81 & 3.78 & 10.00 \\
\hline Isoleucine & 6.62 & 7.77 & 7.43 & 7.27 & 7.51 & 23.00 \\
\hline Leucine & 12.23 & 15.16 & 14.61 & 14.22 & 14.46 & 44.10 \\
\hline Lysine & 11.53 & 14.84 & 14.15 & 14.40 & 13.51 & 41.10 \\
\hline Methionine & 4.75 & 10.17 & 7.18 & 7.62 & 5.70 & 9.50 \\
\hline Phenylalanine & 7.40 & 9.56 & 9.27 & 8.88 & 9.57 & 21.30 \\
\hline Threonine & 6.63 & 8.93 & 8.67 & 8.22 & 8.81 & 30.50 \\
\hline Tryptophan & 0.78 & 0.87 & 0.80 & 0.80 & 0.68 & ND \\
\hline Valine & 8.46 & 10.64 & 10.20 & 10.00 & 10.40 & 42.00 \\
\hline Alanine & 20.33 & 25.63 & 25.40 & 24.24 & 28.84 & 115.70 \\
\hline Arginine & 20.08 & 25.37 & 24.73 & 23.57 & 26.98 & 75.30 \\
\hline Aspartic acid & 18.40 & 22.59 & 21.69 & 21.04 & 22.77 & 81.70 \\
\hline Glutamic acid & 29.20 & 35.65 & 34.95 & 33.93 & 38.15 & 93.40 \\
\hline Glycine & 44.60 & 53.59 & 53.36 & 51.31 & 61.88 & 282.50 \\
\hline Proline & 26.54 & 33.50 & 33.30 & 31.05 & 36.39 & 107.50 \\
\hline Hydroxyproline & 22.73 & 29.23 & 28.38 & 27.09 & 32.11 & ND \\
\hline Serine & 8.65 & 10.88 & 10.65 & 10.47 & 10.58 & 29.20 \\
\hline Tyrosine & 4.36 & 6.35 & 6.03 & 5.88 & 4.34 & 6.30 \\
\hline Cysteine & 1.26 & 1.81 & 1.75 & 1.70 & 1.85 & 1.80 \\
\hline Total & 257.95 & 327.42 & 317.42 & 306.50 & 338.31 & 1014.90 \\
\hline Imino acids (Hyp+Pro) & 49.27 & 62.73 & 61.68 & 58.14 & 68.50 & 107.50 \\
\hline - & & & & & \\
\hline
\end{tabular}

ND - not detected. "Chicken Feet: Literature results by Liu et al. (2001).

\section{Colour Measurement of Collagen}

Table 4 shows colour of duck feet collagen treated with EDTA and different soaking time, commercial bovine and fish collagen. The colour intensity of lightness $\left(\mathrm{L}^{*}\right)$, redness $\left(a^{*}\right)$ and yellowness $\left(b^{*}\right)$ for duck feet collagen increased with longer soaking time.

This result shows that longer soaking time could cause collagen powder to become lighter, more reddish and yellowish. The EDTA treated collagen possessed significantly lower lightness (79.26), higher redness (2.81) and yellow colour (31.46). Thus, it would not be desirable to improve the lightness colour of sardine surimi. The low intensity of lightness and high intensity of yellowness was due to the high-fat content in collagen samples. The intensity of lightness for bovine and fish collagen was significantly higher $(p<0.05)$ than duck feet collagen whereas the redness and yellowness were significantly lower $(p<0.05)$ than duck feet collagen.

Duck feet collagen was much lighter (79.26-89.82) compare to the lightness $(66.85-69.20)$ of chicken feet [3].
The intensity of redness $(0.09-2.81)$ was lower than chicken feet $(2.27-4.47)$. The $a^{*}$ value (redness) collagen is important as it could affect the quality of the dark flesh surimi. Duck feet collagen with lighter colour could improve the lightness of the dark fresh surimi when added to it, so it can enhance the aesthetic properties of the dark flesh surimi.

TABLE IV

THE COLOUR VALUES OF DEMINERALIZED DuCK FEet COLLAGEN

\begin{tabular}{|l|l|l|l|}
\hline \multicolumn{1}{|c|}{ Sample } & $\begin{array}{c}\text { Lightness } \\
\left(\mathbf{L}^{*}\right)\end{array}$ & Redness $\left(\mathbf{a}^{*}\right)$ & $\begin{array}{c}\text { Yellowness } \\
\left(\mathbf{b}^{*}\right)\end{array}$ \\
\hline $12 \mathrm{~h}$ & $89.82 \pm 0.02^{\mathrm{bc}}$ & $0.09 \pm 0.02^{\mathrm{d}}$ & $10.18 \pm 0.03^{\mathrm{c}}$ \\
\hline $24 \mathrm{~h}$ & $89.87 \pm 0.01^{\mathrm{bc}}$ & $0.11 \pm 0.01^{\mathrm{c}}$ & $10.29 \pm 0.03^{\mathrm{f}}$ \\
\hline $36 \mathrm{~h}$ & $89.90 \pm 0.02^{\mathrm{bc}}$ & $0.12 \pm 0.01^{\mathrm{c}}$ & $10.83 \pm 0.03^{\mathrm{d}}$ \\
\hline $48 \mathrm{~h}$ & $91.26 \pm 0.01^{\mathrm{ab}}$ & $0.36 \pm 0.02^{\mathrm{b}}$ & $11.57 \pm 0.03^{\mathrm{c}}$ \\
\hline EDTA & $79.26 \pm 0.01^{\mathrm{d}}$ & $2.81 \pm 0.01^{\mathrm{a}}$ & $31.46 \pm 0.03^{\mathrm{a}}$ \\
\hline Bovine & $88.70 \pm 0.04^{\mathrm{c}}$ & $-0.30 \pm 0.01^{\mathrm{e}}$ & $14.81 \pm 0.01^{\mathrm{b}}$ \\
\hline Fish & $92.55 \pm 0.02^{\mathrm{a}}$ & $-0.750 .01^{\mathrm{f}}$ & $10.650 .02^{\mathrm{e}}$ \\
\hline
\end{tabular}

Values are mean \pm standard deviation.

abcdef :Means within the same column with different letters are significantly different $(\mathrm{p}<0.05)$. 


\section{E. Fourier Transform Infrared (FTIR) Spectroscopy}

Table 5 shows the FTIR peak location and assignment for the variously treated duck feet collagen, commercial bovine and fish collagen. The amide $\mathrm{A}$ bands position were in between 3400 to $3440 \mathrm{~cm}-1$, in which a free N-H stretching vibration occurs. The position of the band will normally move to a lower frequency, $3300 \mathrm{~cm}-1$ when there is a hydrogen bonding in the NH group of a peptide [36]. The infrared spectrum shows that the duck feet collagen which was soaked for $12,24,36$ and $48 \mathrm{~h}$ contained a free N-H stretching (12h, $3416 \mathrm{~cm}-1,24 \mathrm{~h}, 3419 \mathrm{~cm}-1,36 \mathrm{~h}, 3417 \mathrm{~cm}-1$, 48h, $3420 \mathrm{~cm}-1)$. Duck feet collagen which has been demineralized by EDTA contained N-H stretching too (3400 $\mathrm{cm}-1$ ). The amide A band of commercial bovine and fish collagen was found at $3293 \mathrm{~cm}-1$, indicating that there was a hydrogen bonding in the NH group of the peptide.

According to reference [37], the amide B position at 2920 $\mathrm{cm}-1$ is related to $\mathrm{CH} 2$ asymmetrical stretching whereas $2853 \mathrm{~cm}-1$ is related to $\mathrm{CH} 2$ symmetrical stretching. There was a $\mathrm{CH} 2$ asymmetrical stretching and $\mathrm{CH} 2$ symmetrical stretching occur in all the collagen samples $(12 \mathrm{~h}, 2925 \mathrm{~cm}-1$ and $2864 \mathrm{~cm}-1,24 \mathrm{~h}, 2926 \mathrm{~cm}-1$ and $2854 \mathrm{~cm}-1,36 \mathrm{~h}, 2926$ $\mathrm{cm}-1$ and $2854 \mathrm{~cm}-1,48 \mathrm{~h}, 2926 \mathrm{~cm}-1$ and $2854 \mathrm{~cm}-1$, EDTA, $2926 \mathrm{~cm}-1$ and $2854 \mathrm{~cm}-1$, bovine, $2957 \mathrm{~cm}-1$ and $2874 \mathrm{~cm}-1$, fish, $2952 \mathrm{~cm}-1$ and $2869 \mathrm{~cm}-1$ ).

The amide $\mathrm{I}$ band is associated with $\mathrm{C}=\mathrm{O}$ stretching and is found in the range of 1600-1690 cm-1. All the amide I band position of collagen samples fitted the range for amide I band position. The amide I band position of duck feet collagen soaked for $12 \mathrm{~h}, 24 \mathrm{~h}, 36 \mathrm{~h}, 48 \mathrm{~h}$, treated with EDTA, bovine and fish collagen were observed at $1652 \mathrm{~cm}-1,1652$ cm-1, $1656 \mathrm{~cm}-1,1661 \mathrm{~cm}-1,1652 \mathrm{~cm}-1,1652 \mathrm{~cm}-1$ and $1655 \mathrm{~cm}-1$ respectively. The $1655 \mathrm{~cm}-1$ peak normally corresponds to the $\alpha$-helix conformation [38].

The amide II band position of all the duck feet collagen samples were detected around $1592 \mathrm{~cm}-1$ (12h, $1591 \mathrm{~cm}-1$, 24h, $1593 \mathrm{~cm} 1,36 \mathrm{~h}, 1592 \mathrm{~cm}-1$, 48h, $1592 \mathrm{~cm}-1$, EDTA, $1592 \mathrm{~cm}-1)$, fitting well the range of amide II band position [37]. The amide II band position of bovine and fish collagen was found at $1541 \mathrm{~cm}-1$ and $1542 \mathrm{~cm}-1$ respectively, which has been shifted to a lower frequency, indicating that there was hydrogen bonding in the commercial bovine and fish collagen. There is an involvement of C-N stretching and $\mathrm{N}$ $\mathrm{H}$ bending in the collagen samples [38].

The amide III (1229-1301 cm-1) bands are associated with $\mathrm{C}-\mathrm{N}$ stretching and $\mathrm{N}-\mathrm{H}$ and related with the triple helical structure of collagen [37]. There were absorption peaks found in the range of $1241 \mathrm{~cm}-1$ to $1265 \mathrm{~cm}-1$ in all the collagen samples.

\section{F. Folding Test, Cooking Loss, Expressible Moisture (EM) and Water Holding Capacity (WHC)}

Folding test has been used to grade the elasticity and gel quality of surimi [39], [40]. The score of folding test for sardine surimi and different collagen (duck feet, bovine, and fish) added to sardine surimi is shown in Table 6. There was a significant difference $(\mathrm{p}<0.05)$ between sardine surimi (3.00) without and with the addition of collagen (5.00). Sardine surimi cracked gradually when folded in half whereas sardine surimi added with collagen do not crack when folded twice. This result indicates that the addition of duck feet collagen was able to improve the poor quality of sardine surimi.

Determination of cooking loss is fundamental for the meat industry to estimate the characteristic of the products during cooking due to non-meat ingredients or other elements [30]. From Table 6, it shows that there was a significant difference $(\mathrm{p}<0.05)$ for cooking loss between the different treated duck feet collagen. The cooking loss for sardine surimi was significant higher $(\mathrm{p}<0.05)$ than surimi that added with $2 \%$ of duck feet collagen, commercial bovine and fish collagen. Sardine surimi added with collagen which soaked for $36 \mathrm{~h}$ showed the lowest cooking loss among the surimi samples. This is indicating that duck feet collagen which soaked for $36 \mathrm{~h}$ can effectively improve the quality of sardine surimi by reducing the cooking loss and increasing the binding properties. Reference [41] reported that addition of $1 \%$ and above of pork collagen in frankfurter could significantly improve the cooking yields of frankfurter.

The WHC normally shows the degree of denaturation of proteins and water content [42]. According to reference [43], WHC of processed products can be improved by collagen. From the result observed, the cooking loss percentage of surimi gels decreased as the percentage of WHC increased indicating cook loss was inversely associated with WHC. The WHC for sardine surimi was significantly lower $(\mathrm{p}<0.05)$ than different treated duck feet collagen, commercial bovine, and fish collagen. Sardine surimi added with duck feet collagen showed significant higher $(p<0.05)$ WHC than sardine surimi added with commercial bovine and fish. It is clear that duck feet collagen has higher ability to improve WHC of sardine surimi gels compared with commercial bovine and fish collagen. Sardine surimi added with duck feet collagen soaked for $36 \mathrm{~h}$ showed the highest WHC (98.83\%) among the samples. A high percentage of WHC indicated that there was high water retention in the surimi gels as the matrix formed in the gels has better capability to entrap water [30].

EM is associated with WHC. High EM represents low WHC [44]. The water retention in the gels was associated with the strength of the network formed. Thus, the high EM in gels indicated that the poor gel-forming ability of the proteins in the samples [45]. The EM sardine surimi added with duck feet, bovine and fish collagen were significantly lower $(\mathrm{p}<0.05)$ than the sardine surimi without collagen added. It could be suggested that surimi added with duck feet collagen soaked for $36 \mathrm{~h}$ had the highest gel strength as it had lowest EM compared to the other samples. Reference [46] reported that the addition of pork collagen in boneless cured ham resulted in higher EM compared with those without the addition of pork collagen. 
TABLE V

FTIR PEAK LOCATION AND ASSIGNMENT OF DEMINERALIZED DUCK FEET COLLAGEN

\begin{tabular}{|l|l|l|l|l|l|l|l|l|}
\hline \multicolumn{9}{|c|}{ Peak wavenumber $/ \mathbf{c m}^{-1}$} \\
\hline Region & $\mathbf{1 2 h}$ & $\mathbf{2 4 h}$ & $\mathbf{3 6 h}$ & $\mathbf{4 8 h}$ & EDTA & Bovine & Fish & Assignment \\
\hline Amide A & 3416 & 3419 & 3417 & 3420 & 3400 & 3293 & 3293 & NH stretch coupled with hydrogen bond \\
\hline Amide B & 2925 & 2926 & 2926 & 2926 & 2926 & 2957 & 2952 & $\mathrm{CH}_{2}$ asymmetrical stretch \\
\hline & 2864 & 2854 & 2854 & 2854 & 2854 & 2874 & 2869 & $\mathrm{CH}_{2}$ symmetrical stretch \\
\hline Amide I & 1652 & 1652 & 1656 & 1661 & 1652 & 1652 & 1655 & $\mathrm{C}=\mathrm{O}$ stretch/ Hydrogen bond coupled with CN stretch \\
\hline Amide II & 1591 & 1593 & 1592 & 1592 & 1592 & 1541 & 1542 & NH bend coupled with CN stretch \\
\hline Amide III & 1242 & 1241 & 1242 & 1265 & 1242 & 1243 & 1244 & NH bend coupled with CN stretch \\
\hline
\end{tabular}

TABLE VI

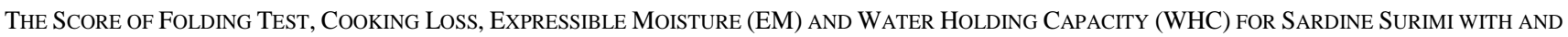
WITHOUT ADDITION OF COLLAGEN

\begin{tabular}{|l|l|l|l|l|}
\hline Samples & Folding Test & \multicolumn{1}{|c|}{ Cook Loss $(\%)$} & EM $(\%)$ & WHC (\%) \\
\hline Sardine surimi & $3.00 \pm 0.00^{\mathrm{b}}$ & $6.59 \pm 0.14^{\mathrm{a}}$ & $25.34 \pm 0.39^{\mathrm{a}}$ & $96.58 \pm 0.30^{\mathrm{f}}$ \\
\hline with DFC 12 h & $5.00 \pm 0.00^{\mathrm{a}}$ & $5.46 \pm 0.12^{\mathrm{c}}$ & $11.68 \pm 0.07^{\mathrm{d}}$ & $98.16 \pm 0.20^{\mathrm{bc}}$ \\
\hline with DFC 24 h & $5.00 \pm 0.00^{\mathrm{a}}$ & $4.59 \pm 0.05^{\mathrm{d}}$ & $11.41 \pm 0.15^{\mathrm{de}}$ & $98.55 \pm 0.70^{\mathrm{ab}}$ \\
\hline with DFC 36 h & $5.00 \pm 0.00^{\mathrm{a}}$ & $4.16 \pm 0.04^{\mathrm{f}}$ & $11.05 \pm 0.07^{\mathrm{e}}$ & $98.83 \pm 0.06^{\mathrm{a}}$ \\
\hline with DFC 48h & $5.00 \pm 0.00^{\mathrm{a}}$ & $4.38 \pm 0.05^{\mathrm{e}}$ & $11.61 \pm 0.16^{\mathrm{d}}$ & $98.72 \pm 0.02^{\mathrm{ab}}$ \\
\hline with DFC (EDTA) & $5.00 \pm 0.00^{\mathrm{a}}$ & $5.38 \pm 0.06^{\mathrm{c}}$ & $11.63 \pm 0.12^{\mathrm{d}}$ & $98.42 \pm 0.05^{\mathrm{bc}}$ \\
\hline with bovine collagen & $5.00 \pm 0.00^{\mathrm{a}}$ & $5.55 \pm 0.10^{\mathrm{b}}$ & $13.21 \pm 0.43^{\mathrm{b}}$ & $97.13 \pm 0.20^{\mathrm{e}}$ \\
\hline with fish collagen & $5.00 \pm 0.00^{\mathrm{a}}$ & $5.48 \pm 0.05^{\mathrm{bc}}$ & $12.33 \pm 0.77^{\mathrm{c}}$ & $97.84 \pm 0.27^{\mathrm{d}}$ \\
\hline
\end{tabular}

Values are mean \pm standard deviation.

${ }^{a b}$ Means within the same column with different letters are significantly different $(\mathrm{p}<0.05)$.

\section{G. Gel Strength Texture Profile Analysis (TPA) of Surimi} Gel

Gel strength is the major indicator for the determination of surimi quality. A high level of gel strength is associated with high amount of concentrated myofibrillar proteins and low amount of sarcoplasmic proteins [47]. According to reference [48], the gel-forming ability is a parameter for determination of the quality of fish proteins. The major types of bonds that involve the building of a network structure during gelation including salt linkages, hydrogen bonds, disulphide bonds and hydrophobic interactions. Myosin has an influence on the gel-forming ability of surimi. The gelforming ability decreases as myosin denaturated [49].

From the result observed (Table 7), duck feet collagen had greater ability to increase the gel strength of sardine surimi significantly compared to commercial bovine and fish collagen. Reference [50] stated that gel strength is associated with WHC. Surimi which has higher WHC will possess stronger gel strength. Thus, sardine surimi which added with duck feet collagen soaked for $36 \mathrm{~h}$ had the highest gel strength (2681.58 g.mm) as it had the highest WHC among the samples.

The TPA of the samples is also shown in Table 7. In general, the addition of duck feet, fish, and bovine collagen gives significant effect on the hardness, springiness, cohesiveness, gumminess, and chewiness of sardine surimi. The protein content of the surimi samples has a significant effect on the hardness of surimi gels whereas its protein quality affects the elasticity of surimi gels [51]. The hardness for sardine surimi added with duck feet collagen which soaked for $36 \mathrm{~h}$ was significant higher $(\mathrm{p}<0.05)$ than duck feet collagen which soaked for $12 \mathrm{~h}, 24 \mathrm{~h}$, and $48 \mathrm{~h}$. Sardine surimi added with commercial bovine and fish collagen was significantly lower $(\mathrm{p}<0.05)$ in hardness compared to sardine surimi added with duck feet collagen.

TABLE VII

Gel STRENGTH AND TEXTURE PROFILE ANALYSIS FOR SARDINE SURIMI

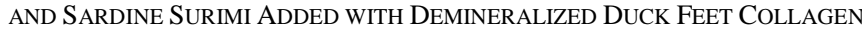

\begin{tabular}{|c|c|c|c|c|c|c|}
\hline Sample & $\begin{array}{l}\text { Gel Strength } \\
\text { (g.mm) }\end{array}$ & $\begin{array}{l}\text { Hardness } \\
\text { (kg) }\end{array}$ & $\begin{array}{l}\text { Springiness } \\
(\mathbf{m m})\end{array}$ & $\begin{array}{l}\text { Cohesiveness } \\
\text { (ratio) }\end{array}$ & $\begin{array}{l}\text { Gumminess } \\
(\mathrm{kg})\end{array}$ & $\begin{array}{l}\text { Chewiness } \\
\text { (kg.mm) }\end{array}$ \\
\hline Sardine surimi & $280.43 \pm 5.13^{c}$ & $1.22 \pm 0.12^{\mathrm{f}}$ & $14.90 \pm 0.06^{\mathrm{c}}$ & $0.22 \pm 0.02^{f}$ & $0.26 \pm 0.03^{\mathrm{e}}$ & $3.49 \pm 0.12^{f}$ \\
\hline with DFC $12 \mathrm{~h}$ & $2655.00 \pm 63.20^{\mathrm{a}}$ & $6.07 \pm 0.05^{\mathrm{c}}$ & $15.00 \pm 0.04^{b}$ & $0.50 \pm 0.02^{\mathrm{d}}$ & $3.09 \pm 0.11^{\mathrm{b}}$ & $45.27 \pm 0.45^{b c}$ \\
\hline with DFC 24 h & $2635.81 \pm 107.77^{\mathrm{a}}$ & $6.38 \pm 0.13^{b}$ & $15.02 \pm 0.12^{b}$ & $0.55 \pm 0.02^{b}$ & $3.12 \pm 0.07^{\mathrm{b}}$ & $48.02 \pm 0.59^{\mathrm{a}}$ \\
\hline with DFC 36 h & $2681.58 \pm 105.22^{\mathrm{a}}$ & $6.53 \pm 0.07^{\mathrm{a}}$ & $15.24 \pm 0.11^{\mathrm{a}}$ & $0.59 \pm 0.02^{\mathrm{a}}$ & $3.25 \pm 0.11^{\mathrm{a}}$ & $48.71 \pm 0.84^{\mathrm{a}}$ \\
\hline with DFC $48 \mathrm{~h}$ & $2631.04 \pm 70.75^{\mathrm{a}}$ & $6.39 \pm 0.07^{b}$ & $15.00 \pm 0.05^{b}$ & $0.54 \pm 0.02^{\mathrm{bc}}$ & $3.05 \pm 0.07^{\mathrm{b}}$ & $48.72 \pm 0.69^{b}$ \\
\hline with DFC (EDTA) & $2625.90 \pm 66.11^{\mathrm{a}}$ & $6.50 \pm 0.06^{\mathrm{ab}}$ & $15.01 \pm 0.06^{\mathrm{b}}$ & $0.53 \pm 0.02^{\mathrm{cd}}$ & $3.05 \pm 0.08^{\mathrm{b}}$ & $44.53 \pm 0.51^{c}$ \\
\hline with bovine collagen & $1701.20 \pm 66.90^{\mathrm{b}}$ & $5.21 \pm 0.13^{\mathrm{d}}$ & $14.99 \pm 0.00^{\mathrm{b}}$ & $0.46 \pm 0.01^{\mathrm{e}}$ & $2.35 \pm 0.07^{\mathrm{c}}$ & $35.32 \pm 0.83^{\mathrm{d}}$ \\
\hline with fish collagen & $1625.20 \pm 133.80^{b}$ & $4.63 \pm 0.14^{\mathrm{e}}$ & $15.01 \pm 0.04^{b}$ & $0.45 \pm 0.00^{\mathrm{e}}$ & $2.08 \pm 0.06^{\mathrm{d}}$ & $31.29 \pm 0.83^{\mathrm{e}}$ \\
\hline
\end{tabular}


Cohesiveness is the work done to decompose the internal bone in surimi [52]. The cohesiveness of the sardine surimi gels has the similar trend with the hardness of the samples. The cohesiveness of the samples has an influence on the hardness of the surimi gels. Hardness values will increase as the cohesiveness values of the surimi gels increase [53].

Cohesiveness value near to 1 shows the recovery of the sample after the initial compression. Sardine surimi added with duck feet collagen soaked for $36 \mathrm{~h}$ showed the highest cohesiveness (0.59) among the samples. This indicates that it has a better recovery than the other samples.Springiness is the rate of surimi to recover to its initial condition after deformation [52]. Sardine surimi added with duck feet collagen soaked for $36 \mathrm{~h}$ had significantly highest $(\mathrm{p}<0.05)$ rate of recovery after compression compared to the other samples. Chewiness is referred to the energy needed to chew the surimi until it is ready to swallow. It is a complementary parameter of hardness [53]. Duck feet collagen had higher significant $(\mathrm{p}<0.05)$ effect on the chewiness and gumminess on sardine surimi compared to commercial bovine and fish collagen.

The study shows that pork collagen has the ability to enhance protein-protein bind in pale soft and exudative (PSE) pork. This indicates that the addition of pork collagen could provide the essential functional protein that is lost due to protein denaturation in PSE pork [46].

\section{H. Colour of Surimi Gels}

Colour is one of the parameter determining the grade of surimi gels other than impurities, moisture content, gel strength and $\mathrm{pH}$ [54]. Colour is also an important quality attributes of foods as it determines the acceptability of the product by consumers. The lightness $\left(\mathrm{L}^{*}\right)$, redness $\left(\mathrm{a}^{*}\right)$ and yellowness $\left(b^{*}\right)$ of the differently treated surimi are presented in Table 8.

Whiteness is the fundamental element deciding the quality and acceptability of surimi gels [55]. Significant differences $(p<0.05)$ were observed in the sardine surimi with or without collagen added. Sardine surimi with duck feet collagen added exhibited significant $(\mathrm{p}<0.05)$ higher intensity in lightness compared to sardine surimi gels added with commercial bovine and fish collagen. The $\mathrm{L}^{*}$ value for sardine surimi added with EDTA treated duck feet collagen was significantly lower $(\mathrm{p}<0.05)$ than sardine surimi added with duck feet collagen soaked for a different time. This could be due to the low intensity of lightness for the EDTA treated duck feet collagen powder. This also indicated that EDTA treated duck feet collagen was not effective to improve the colour to dark flesh surimi.

Duck feet collagen soaked for $12 \mathrm{~h}$ and $36 \mathrm{~h}$, duck feet collagen treated with EDTA and commercial fish collagen did significantly affect $(\mathrm{p}<0.05)$ the redness of sardine surimi whereas the other samples had no significant effect $(p>0.05)$ on the redness of sardine surimi. Since the EDTA treated duck feet collagen powder exhibited much higher $b^{*}$ (31.36) compare to the other collagen powder which possesses $b^{*}$ value in the range of $10.18-14.81$, it provided the significant higher intensity of yellowness for sardine surimi.

TABLE VIII

The Lightness (L*), Redness (A*) AND Yellowness (B*) VALUES OF SARDine SURImI AND SARDINE SuRIMI ADDED WITH DEMINERALIZED Duck FEET CollageN

\begin{tabular}{|c|c|c|c|}
\hline Sample & Lightness $\mathbf{L}^{*}$ & Redness a* & Yellowness $\mathbf{b}^{*}$ \\
\hline Sardine surimi & $61.96 \pm 0.47^{\mathrm{e}}$ & $-1.04 \pm 0.08^{\mathrm{ab}}$ & $13.17 \pm 0.34^{\mathrm{c}}$ \\
\hline with DFC $12 \mathrm{~h}$ & $64.39 \pm 0.10^{\mathrm{b}}$ & $-0.66 \pm 0.13^{\mathrm{d}}$ & $13.45 \pm 0.31^{\mathrm{bc}}$ \\
\hline with DFC $24 \mathrm{~h}$ & $64.45 \pm 0.25^{\mathrm{b}}$ & $-0.86 \pm 0.11^{b c}$ & $13.46 \pm 0.49^{\mathrm{bc}}$ \\
\hline with DFC $36 \mathrm{~h}$ & $64.67 \pm 0.18^{\mathrm{ab}}$ & $-0.79 \pm 0.18^{\mathrm{cd}}$ & $13.33 \pm 0.25^{\mathrm{bc}}$ \\
\hline with DFC $48 \mathrm{~h}$ & $64.85 \pm 0.10^{\mathrm{a}}$ & $-0.95 \pm 0.16^{\mathrm{abc}}$ & $13.39 \pm 0.40^{\mathrm{bc}}$ \\
\hline with DFC (EDTA) & $62.08 \pm 0.19^{\mathrm{e}}$ & $-0.29 \pm 0.13^{\mathrm{e}}$ & $14.61 \pm 0.28^{\mathrm{a}}$ \\
\hline with bovine collagen & $63.58 \pm 0.27^{\mathrm{d}}$ & $-0.86 \pm 0.23^{\mathrm{abc}}$ & $13.23 \pm 0.35^{\mathrm{bc}}$ \\
\hline with fish collagen & $63.98 \pm 0.48^{\mathrm{c}}$ & $-1.07 \pm 0.14^{\mathrm{a}}$ & $13.62 \pm 0.17^{\mathrm{b}}$ \\
\hline
\end{tabular}

Values are mean \pm standard deviation.

abcde :Means within the same column with different letters are significant different $(\mathrm{p}<0.05)$.

\section{CONCLUSIONS}

Duck feet collagen which was soaked for $24 \mathrm{~h}, 36 \mathrm{~h}$ and $48 \mathrm{~h}$ in $5 \%$ lactic acid exhibits nearly similar in chemical composition, which is $7.36-7.48 \%$ for moisture content, $41.59-41.64 \%$ for protein content, $30.19-30.67 \%$ for fat content and $24.36-24.73 \%$ for ash content. The ash content in duck feet has been reduced by soaking in $0.5 \mathrm{M}$ EDTA for $24 \mathrm{~h}$. The intensity of lightness, redness, and yellowness increases with prolonging the soaking time of duck feet collagen. Duck feet collagen soaked for different time $(12 \mathrm{~h}$, $24 \mathrm{~h}, 36 \mathrm{~h}$ and $48 \mathrm{~h}$ ) has no significant difference in yield whereas the swelling percentage for duck feet collagen soaked for $48 \mathrm{~h}$ is significant highest among the samples.
Duck feet collagen has the ability to enhance the quality of low-grade sardine surimi, and its effect is better than commercial bovine and fish collagen. It had significantly increased the gel strength, colour and texture of sardine surimi with the significant lower cooking loss, expressible moisture and higher water holding capacity. Duck feet collagen soaked for $36 \mathrm{~h}$ show the greatest effect to improve the quality of sardine surimi.

\section{ACKNOWLEDGMENT}

The authors are thankful for the support from Universiti Sains Malaysia, Universiti Sultan Zainal Abidin, Mercu Buana University of Yogyakarta and Universiti Kebangsaan 
Malaysia This project was funded through Universiti Sains Malaysia Research University grant 1001/PTEKIND/815081.

\section{REFERENCES}

[1] Department of Veterinary Services Malaysia. Available from: [Online]. http://agrolink.moa.my/jph/dvs/commodities/itik/ducke.html [Accessed $5^{\text {th }}$ March 2016].

[2] Cheng, F.Y., Hsu, F.W., Chang, H.S., Lin, L.C. and Sakata, R. Effect of Different Acids on The extraction of Pepsin-solubilised Collagen Containing Melanin form Silky Fowl Feet. Food Chemistry. 113: 563-567. 2009.

[3] Liu, D.C., Lin Y.K. and Chen, M.T. Optimum Condition of Extracting Collagen from Chicken Feet and its Characteristics. Australasian Journal of Animal Sciences. 14(11): 1638-1644. 2001

[4] Huda, N., Seow E. K., Normawati, M. N., Nik Aisyah, N.M., Fazilah, A. and Easa, A. M. Preliminary Study on Physicochemical Properties of Duck Feet Collagen. International Journal of Poultry Science. 2012.

[5] Huda, N., Seow E. K., Normawati, M. N., Nik Aisyah, N.M., Fazilah, A. and Easa, A. M. Effect of Duck Feet Collagen Addition on the Physicochemical Properties of Surimi, International Food Research Journal. 20(2): 537-544. 2013.

[6] Deyl, Z., Miksik, I. and Eckhardt, A. Preparative Procedures and Purity Assessment of Collagen Proteins. Journal of Chromatography B. 790: 245-275. 2003.

[7] Pachence, J. M. Process for Extracting Type I Collagen from An Avian Source and Applications Therefor. US. Patent. 5138030. 1992.

[8] Li, Shu-Tung. Collagen Biotechnology and Its Medical Application. Biomedical Engineering: Applications, Basis and Communication. 5: 646-657. 1993.

[9] Pachence, J. M. Collagen-based Devices for Soft Tissue Repair. Journal of Biomedical Materials Research. 33: 35-40. 1996.

[10] Angele, P. J., Abke, R., Kujat, H., Faltermerier, D., Schumann, M., Nerlich, B., Kinner, C. Englert, Z., Ruszczak, R., Mehrl and R. Mueller. Influence of Different Collagen Species on Physicochemical Properties of Crosslinked Collagen Matrices. Biomaterials. 25: 2831-2841. 2004

[11] Lee, C. H., Singla, A. and Lee, Y. Biomedical Applications of Collagen. International Journal of Pharmaceutics. 221: 1-22. 2001.

[12] Sadowska, M. I., Koodziejska, and Niecikowska, C. Isolation of Collagen from The Skins of Baltic Cod (Gadus morhua). Food Chemistry. 81(2): 257-262. 2003.

[13] Zayas, J. F. Functionality of proteins in food. Berlin: Springer-Verlag: 6-22. 1997.

[14] Gomez-Guillen, M. C., Gimenez, B., Lopez-Caballero, M. E. and Montero, M. P. Functional and Bioactive Properties of Collagen and Gelatin from Alternative sources: A review. Food Hydrocolloids. 25: 1813-1827. 2011.

[15] Simpson, B. K. Food Biochemistry and Food Processing. John Willey and Sons, New Delhi. 2012.

[16] Gomez-Guillen, M. C., and Montero, P. Extraction of Gelatine from Megrim (Lepidorhombus boscii) Skins with Several Organic Acids. Journal of Food Science. 66(2): 213-216. 2011.

[17] Okada, M. History of Surimi Technology in Japan. In Surimi Technology, (T.C. Lanier and C.M. Lee, eds.) pp. 3-22, Marcel Dekker, New York. 1992.

[18] Hall, G. Fish Processing: Sustainability and New Opportunities, John Wiley and Sons, New Delhi. 2011.

[19] Mukundan, M. K., Suseela, Mathew and Gopakumar K. Nutrients and Nutritional Quality of Pink Perch (Nemiptterus japonicas): Mince and Their Fate on Surimi Manufacturer, In Nutrients and Bioactive Substances in Aquatic Organisms, Eds. K. Devadasan et al, Society of Fisheries Technologists (India), Kochi, India, 215. 1994.

[20] Chaijan, M., Benjakul, S., Visessanguan, W. and Faustman, C. Characteristics and Gel Properties of Muscles from Sardine (Sardinella gibbosa) and Markerel (Rastrelliger kanagurta) Caught in Thailand. Food Research International. 37(10): 1021-1030. 2004.

[21] Chen, H. H. Decoloration and Gel-forming Ability of Horse Mackerel Mince by Air-flotation Washing. Journal of Food Science. 67: 2970-2975. 2002.

[22] Kudre, T., Benjakul, S. and Kishimura, H. Effect of Protein Isolates from Black Bean and Mungbean on Proteolysis and Gel Properties of Surimi from Sardine (Sardinella albella). Food Science and Technology. 50(2): 511-518. 2013.
[23] Skierka, E., Sadowska, M. and Karwowska, A. Optimum Condition for Demineralization Baltic Cod (Gadus morhua) Backbone. Food Chemistry. 105: 215-218. 2007.

[24] Nurkhoeriyati, T., Huda, N. and Ahmad, R. Gelation Properties of Spent Duck Meat Surimi-Like Material Produced Using AcidAlkaline Solubilization Methods. Journal of Food Science. 76(1): 4855. 2011.

[25] Ockerman, W. H. Quality Control of Post-mortem Muscle Tissue. The Ohio State University, Ohio, USA, p. 51. 1984.

[26] Association of Official Analytical Chemists (AOAC). Official Methods of Analysis. 17 ${ }^{\text {th }}$ Edition. Washington DC: Association of Official Analytical Chemists. 2000.

[27] Sarwar, G., Christensen, D. A., Finalayson, A. J., Friedman, M., Hackler, L. R., Mackenzie, S. L., Pellett, P. L. and Tkachuk, R. Inter- and Intra-Laboratory Variation in Amino Acid Analysis of Food Proteins. Journal of Food Science. 48: 526-531. 1983.

[28] Woo, J., Yu, S., Cho, S., Lee, Y. and Kim, S. Extraction Optimization and Properties of Collagen from Yellofin Tuna (Thunnus albacares) Dorsal Skin. Food Hydrocolloids. 22: 879-887. 2008.

[29] Lanier, T. C. Measurement of Surimi Composition and Functional Properties. In: Surimi Technology, (T.C. Larnier and C.M. Lee, Editors). Marcel Dekkel Inc, New York. 1992.

[30] Pietrasik, Z., and Li-Chan, E. C. Y. Binding and Textural Properties of Beef Gels as Affected by Protein, K-carrageenan and Microbial Transglutaminase Addition. Food Research International. 35: 91-98. 2002.

[31] Benjakul, S., Visessangun, W. and Srivilai, C. Gel Properties of Bigeye Snapper (Priacanthus tayenus) Surimi as Affected by Setting and Porcine Plasma Protein. Journal of Food Quality. 24: 453-471. 2001.

[32] Benjakul, S., Vissessanguan, W. and Tueksuban, J. Changes in Physic-chemical Properties and Gel-forming Ability of Lizardfish (Saurida tumbil) during Post-mortem Storage in Ice. Food Chemistry. 80(4): 535-544. 2003.

[33] Tabilo-Munizaga, G. and Barbosa-Canovas, G. V. Color and Textural Parameters of Pressurized and Heattreated Surimi Gels as Affected by Potato Starch and Egg White, Food Research International. 37: 767-775. 2004.

[34] Wangtueai, S. and Noomhorm, A. Processing Optimization and Characterization of Gelatin from Lizardfish (Saurida spp.) Scales. Food Science and Technology. 42: 825-834. 2009.

[35] Johnston-Banks, F. A. Gelatin. In Harris, P. (Eds.). Food Gelatin, p. 233-289. New York: Elsevier Applied Sciences. 1990.

[36] Li, H., Liu, B. L., Gao, L. Z. and Chen, H. L. Studies on Bullfrog Skin Collagen. Food Chemistry. 84: 65-69. 2004.

[37] Palpandi, C., Ramasamy, P. and Pajinikanth, T. Extraction of Collagen from Mangrove archeaogastropod Nerita (Dostia) crepidularia Lamarck. American-Eurasian Journal of Scientific Research. 5(1): 23-30. 2010.

[38] Andriana, A. and Gabi. D. Rapid Characterization of Peptide Secondary Structure by FT-IR Spectroscopy, Revue. Roumaine de. Chimie. 56(8): 783-791. 2011.

[39] Botta, J.R. Evaluation of Seafood Freshness Quality, New York: VCH Publisher, Inc. 1995

[40] Hsu, S. Y. Optimation of the Surimi Processing System with a Central Composite Design Method. Journal of Food Engineering. 24(1): 101-111. 1995.

[41] Prabhu, G.A., Doerscher, D.R. and Hull, D.H. Utilization of Pork Collagen Protein in Emulsified and Whole Muscle Meat Products. Journal of Food Science. 69: 388-389. 2004.

[42] Shaviklo, G.Z. Quality Assessment of Fish Protein Isolates Using Surimi Standard Methods. The United Nations University, Fisheries Training Programme. Ice Land. 2006.

[43] Webster, J. D., Ledward, D. A. and Lawrie, R. A. Protein Hydrolysates from Meat Industry by-products. Meat Science. 7: 14767. 1982.

[44] Chaijan, M., Benjakul, S., Visessanguan, W. and Fautsman, C. Physichochemical Properties, Gel-forming Ability and Myoglobin Content of Sardine (Sardinella gibbosa) and Mackerel (Rastrelliger kanagurta) Surimi Produced by Conventional Method and Alkaline Solubilisation Process. European Food Research Technology. 222(12): $58-63.2006$

[45] Karthikeyan, M., Shamasundar, B.A., Mathew, S., Kumar, P.R. and Prakash, V. Physico-chemical and Functional Properties of Proteins from Pelagic Fatty Fish (Sardinella longiceps) as A Function of 
Water Washing. International Journal of Food Properties. 7: 353-365. 2004.

[46] Schilling, M.W., Mink, L.E., Gochenour, P.S., Marriot, N.G. and Alvarado, C.Z. Utilization of Pork Collagen for Functionality Improvement of Boneless Cured Ham Manufactured from Pale, Soft, and Exudative Pork. Meat Science. 65: 547-5532003..

[47] Ensoy, U., Kolsarici, N. and Candogan, K. Quality Characteristics of Spent Layer Surimi during Frozen Storage. European Food Research and Technology. 219(1): 14-19. 2004.

[48] Sen, D.P. Advances in Fish Processing Technology. Allied publishers PVT. LTD, New Delhi. 2005.

[49] Pan. J, Shen. H. and Luo. Y. Cryoprotective Effects of Trehalose on Grass Carp (Ctenopharyngodon idellus) Surimi during Frozen Storage. Journal of Food Processing Preservation. 34(4): 715-727. 2010.

[50] Benjakul, S., Visessanguan, W., Riebroy, S., Ishizaki, S. and Tanaka, M. Gel-forming properties of Surimi Produced from Bigeye Snapper, Priacanthus Tayenus and P. Macracanthus, Stored in Ice. Journal of the Science of Food and Agriculture. 82(13): 1442-1451. 2002.

[51] Martinez, I. Water Retention Properties and Solubility of the Myofibrillar Proteins: Interrelationships and Possible Values as
Indicators of the Gel Strength in Cod Surimi by a Multivariate Data Analysis. Journal of the Science of Food and Agriculture. 46(4): 469479. 1989.

[52] Luo, X., Yang, R., Zhao, W., Cheng, Z. and Jiang, X. Gelling Properties of Spanish Mackerel (Scomberomorus niphonius) Surimi as Affected by Washing Process and High Pressure. International Journal of Food Engineering. 6(4): 1-17. 2010.

[53] Nopianti, R., Huda, N., Fazilah, A., Ismail, N., and Easa, A. M. Effect of Different Types of Low Sweetness Sugar on Physicochemical Properties of Threadfin Bream Surimi (Nemipterus spp.) during Frozen Storage. International Food Research Journal. 19(3): 1011-1021. 2012.

[54] Burden, M., Sylvia, G. and Kolbe, E. Optimal Storage Temperature Design Frozen Seafood Inventories: Application to Pacific Whiting Surimi. In: Proceedings of the Twelfth Biennial Conference of the International Institute of Fisheries Economics and Trade, July 21-30, 2004, Tokyo, Japan, pp. 1-13. 2004.

[55] Yoon, W. B., Park, J. W. and Kim, B. Y. Linear Programming in Blending Various Components of Surimi Seafood. Journal Food Science. 62: 561-567. 1997 